\title{
NosSa LíngUa PORTUGUESA, FERIDA, MALFALADA E MAL ESCRITA
}

É indiscutível que a língua de qualquer povo é dinâmica, sofre significativas mudanças que acompanham os progressos e evolução dos pensamentos, da intelectualidade e da ciência. Tal fato tem ocorrido também com nossa querida língua mãe, tão maravilhosamente decantada nos versos de Camões. No entanto, é desejável e salutar que as mudanças ocorram a partir e de dentro da sociedade, das vivências e da evolução da mesma. Infelizmente, nos últimos anos, temos assistido em nosso País a uma indesejável descaracterização da nossa língua falada e escrita. É triste a constatação de que tal fenômeno seja observado também na redação de trabalhos científicos publicados em revistas médicas nacionais. É desnecessário dizer que essa verdadeira agressão é provocada pela nefasta influência da língua inglesa, intensificada nos últimos anos pela globalização da cultura, pela massificação das informações veiculadas pela televisão, pela popularização no uso dos computadores e, mais recentemente, pelo surgimento das operadoras de "telemarketing", este último verdadeiro destruidor da nossa língua e perturbador do nosso sossego domiciliar. Devemos reconhecer que junto a esse fenômeno, a medicina brasileira vem sofrendo também forte influência norte-americana, tornando-se mecanicista e pouco voltada à saudável relação direta do médico com seu paciente.

Nós médicos temos o exemplo em nossa atividade diária: a enfermeira que nos solicita se "poderíamos estar avaliando um paciente" ou outro jovem residente que nos pergunta: "amanhã o senhor vai poder estar ajudando determinada cirurgia?". A utilização descabida do presente ou futuro do gerúndio, lícita do ponto de vista gramatical, porém deselegante e imoral do ponto de vista ético, constitui um dos exemplos mais freqüentes e marcantes de agressão a nossa língua falada. Na linguagem escrita, particularmente nos textos médicos, verificamos a utilização exagerada de adjetivos, refletindo também marcante influência da língua inglesa. É comum a utilização de expressões pedantes, como "paciente pediátrico", "quadril infantil" ou "transplante hepático pediátrico", termos que poderiam até ser considerados gramaticalmente corretos, porém destituídos de bom senso lingüístico. Tais expressões poderiam ser honestamente substituídas por "paciente criança", "quadril da criança" ou "transplante de fígado na criança". Outra dolorosa constatação é a introdução de neologismos, a partir dos termos em inglês, que não encerram qualquer semelhança ou significado em nossa língua. Neste caso, o exemplo mais significativo é a utilização do termo "paciente crítico", em lugar de "doente gravemente enfermo", inadequação freqüentemente empregada até em títulos de livros médicos. Também, termos oriundos diretamente do inglês, como "revisitar" ou "estado da arte", empregados geralmente em títulos de aulas e temas de congressos, poderiam ser apropriadamente substituídos por "revisão" ou "atualização", mais condizentes com nossa forma de expressão. Esperemos que esta onda maléfica se desfaça rapidamente sem deixar cicatrizes deformantes em nossa língua.

Em determinadas universidades brasileiras, no entanto, somos testemunhas de que se enfatiza a necessidade do emprego da escrita correta na elaboração de teses, memoriais e textos destinados ao ensino de alunos e residentes. É necessário que esta postura não fique restrita aos muros das instituições de ensino e se expanda a toda sociedade.

É importante e imprescindível que os médicos responsáveis pelo ensino de graduação, educação continuada e aqueles encarregados da edição e revisão de textos cientíícos, adquiram o hábito de se expressar de forma a manter a estruturapadrão da nossa língua. Devemos ter competência para rechaçar toda e qualquer influência externa maléfica sobre nossa forma de falar e escrever, e que eventuais mudanças deverão atender à evolução do nosso meio e de nossa sociedade. É nossa função banir a onda do "gerundismo" exagerado, do uso de adjetivos em excesso e da importação de termos em inglês sem significado correspondente em nossa língua. Lembremos o que sempre nos mostrou a História das civilizações, que a destruição da cultura de um povo começa pela destruição de sua língua nativa.

Uenis TannurI 